Revista Transgressões: ciências criminais em debate, v. 5, n. 2, Outubro 2017, Natal/RN

\title{
JUSTIÇA DE TRANSIÇÃO: AS “AVÓS DA PRAÇA DE MAIO” COMO INSTRUMENTOS DO DIREITO À IDENTIDADE E À VERDADE HISTÓRICA ARGENTINA
}

\section{Luana Gonçalves Salignac}

Vinculada à Universidade Federal do Amazonas.

E-mail: luanasalignac@hotmail.com

\section{RESUMO}

0 artigo pretende comprovar a eminente contribuição das "Avós da Praça de Maio" para a Justiça de Transição e, consequentemente, para a sociedade argentina, tendo em vista seus trabalhos dedicados à descoberta da verdade, com destaque à histórica e à biológica, as quais possibilitam a restituição do direito à identidade das crianças sequestradas pelo Estado durante a ditadura militar argentina (1976-1983). Para tanto, utiliza-se o método dialógico, abordando o tema em conjunto com diversas áreas do conhecimento além do direito, como com a antropologia, com a biologia, com a história e com a sociologia. Combatendo o crime de apropriação, as "Avós da Praça de Maio" são respaldadas jurídica e cientificamente para realizarem investigações, coleta de dados, pesquisas, exames de DNA e reparação psicológica daqueles que tiveram a identidade restituída, o que consagra sua organização como modelo internacional de um ativismo restaurador da memória e garantidor da justa transição à democracia.

PALAVRAS-CHAVE: Justiça de Transição. Direito à identidade. Direito à verdade. Avós da Praça de Maio. Ditadura militar argentina. 


\section{INTRODUÇÃO}

As “Avós da Praça de Maio" constituem uma organização não-governamental fundada na Argentina em 1977, um ano após o golpe de Estado liderado pelo então general Jorge Rafael Videla. A ditadura intitulada Proceso de Reorganización Nacional ${ }^{19}$ deu início, no dia 24 de março de 1976, aos anos mais violentos da história argentina, os quais chegariam ao fim apenas em 1983. Ela foi justificada pelos militares como a solução para "combater o terrorismo marxista-leninista e, gradualmente, instaurar uma verdadeira democracia" (VALENTI, 2014). Durante esse período, as violações aos direitos humanos eram constantes, resultados da repressão dos militares a quaisquer opositores do regime. Eles eram sequestrados e levados a centros clandestinos de detenção, onde eram interrogados, torturados e, na maioria das vezes, mortos.

Em 22 de outubro de 1977, 12 mães reuniram-se pela primeira vez na Praça de Maio, em Buenos Aires, alegando que suas filhas haviam sido raptadas ainda grávidas ou com bebês recém-nascidos. Com o tempo, outras mulheres que passavam por semelhante situação aderiram ao grupo, até se firmarem como uma organização proativa e com objetivos delimitados: as Abuelas de Plaza de Mayo. Suas investigações constataram que, dentre as mais de 30.000 pessoas desaparecidas, 500 eram crianças que foram usadas como "espólios de guerra" ${ }^{, 20}$. Elas foram apropriadas por simpatizantes da ditadura ou pelos próprios militares atuantes nos centros de repressão, tendo sua verdadeira identidade usurpada, assim como seu direito à verdade acerca do ocorrido.

Diante disso, as "Avós" não se limitaram a encontrar seus filhos, vítimas da ditadura, mas reconheceram em sua instituição a possibilidade de reaver o passado de um povo, ao conceder-lhe a verdade histórica; de garantir a justiça às vítimas e aos familiares; de restituir a identidade de seus netos; e de reprimir a reincidência dos crimes contra a dignidade humana no futuro. O conjunto desses objetivos tornam as "Avós da Praça de Maio" um instrumento de significativa relevância social da Justiça de Transição na Argentina, já que unem mecanismos para superar um momento de grandes conflitos e violações sistemáticas aos direitos humanos.

As "Avós" também são importantes à comunidade científica, ao agregarem suas pesquisas à biologia, mais especificamente à genética. Este fato possibilitou o uso dos exames

\footnotetext{
${ }^{19}$ Processo de Reorganização Nacional, em português.

${ }^{20}$ Disponível em: https://www.abuelas.org.ar/abuelas/historia-9
} 
de DNA na comprovação de um passado, a restituição de identidade das crianças apropriadas e a criação do primeiro "Banco Nacional de Dados Genéticos"21 (BNDG) do mundo.

No que tange à relevância jurídica, é fundamental frisar a necessidade de salvaguardar o Estado Democrático de Direito, sendo vital para seu correto funcionamento a garantia da verdade absoluta. $\mathrm{O}$ direito à verdade é um dos pilares da Justiça de Transição, por meio do qual o Estado deve saldar suas dívidas com um passado de violações democráticas e humanitárias. A transição de um período com sistemáticas transgressões aos direitos humanos não pode levar a um estado de amnésia, pelo contrário, é imprescindível a transparência e imparcialidade durante as revelações e os corretos julgamentos.

Ademais, o conteúdo sensibiliza o ser humano, uma vez que envolve violações irreparáveis no campo sentimental; familiares angustiados por não saberem o real paradeiro de seus parentes, sem poderem realizar o direito ao sepultamento dos corpos; casos de tortura; assassinatos brutais e, apesar de tudo, um grupo de mulheres as quais ainda carregam a esperança de uma justiça eficaz: as Abuelas de Plaza de Mayo.

Por meio do método dialógico, busca-se comprovar quais as consequências das investigações das "Avós da Praça de Maio" para a Justiça de Transição e para a sociedade argentina pós-ditatorial, não só pelo viés do direito, mas também pela sociologia, pela história, pela antropologia e pela biologia, já que as "Avós" estão intimamente ligadas ao contexto histórico-social da comunidade argentina. Por isso, faz-se pesquisa, por exemplo, a informações do Banco Nacional de Dados Genéticos argentino, a revistas de Direitos Humanos e de antropologia, a documentários acerca da ditadura, aos registros das "Avós", a Convenções internacionais, entre outros.

Para tanto, analisa-se a apropriação de crianças durante a ditadura militar argentina enquanto parte de um Plano Sistemático de Estado; os trabalhos de pesquisa, de coleta de dados e de investigação das "Avós" são respaldados com base nos fundamentos jurídicos que os tornam legais, considerando a importância da lei $\mathrm{n}^{0}$ 26.548/2009 do Código Penal argentino (Lei de $A D N^{22}$ ); examina-se o processo de restituição de identidade e de reparação psicológica dos apropriados, oferecido pela organização das “Avós da Praça de Maio" e, por fim, será enfatizada a contribuição das "Avós" para a Justiça de Transição, como elemento restaurador da memória histórica da Argentina, como possibilidade de garantir a justiça pela sanção dos responsáveis e como prevenção da repetição dos crimes ocorridos.

\footnotetext{
${ }^{21}$ Criado pela lei 23.511/1989.

${ }^{22}$ ADN é a sigla em espanhol para DNA (ácido desoxirribonucleico).
} 


\section{O PLANO SISTEMÁTICO DE APROPRIAÇÃO DE MENORES}

O terrorismo de Estado era a principal arma das forças de repressão argentinas. Ele se manifestou como uma violência física e mental ilegítima àqueles que declaradamente eram contrários ao regime imposto. Os chamados detenidos-desaparecidos ${ }^{23}$, entre 1976 e 1983, foram sequestrados, torturados e assassinados. Segundo dados da Comisión Nacional sobre la Desaparición de Personas ${ }^{24}$, as vítimas de desaparecimento forçado somam, aproximadamente, 8.961 pessoas. Entretanto, nesse valor incluem-se também 500 figuras que foram abruptamente deslocadas de sua linhagem familiar, perdendo a verdadeira identidade a troco de uma vida falaciosa, subjugadas a uma educação com forte carga ideológica militar: os bebês apropriados, filhos de militantes opositores.

Conforme relatado no documentário "500: Os bebês roubados pela ditadura argentina", as crianças eram sequestradas recém-nascidas, junto a seus pais ou, na maioria das vezes, depois de geradas em um dos mais de 340 centros de repressão da ditadura. A maior das maternidades clandestinas era a Escuela Mecánica de la Armada ${ }^{25}$ (ESMA), pela qual passaram mais de 5.000 desaparecidos. Nesses centros havia médicos responsáveis pela administração local, também coniventes com as violações à dignidade da pessoa humana que lá ocorriam.

Os partos, às vezes, eram feitos pelas próprias companheiras dentro das celas. Alicia Milia $^{26}$, sobrevivente da ESMA, informa que um dos oficiais do centro, Hector Freves, incumbiu-lhe a tarefa de realizar o parto de uma das presas, ainda que Milia não tivesse noção alguma sobre o procedimento. Após o bebê nascer, ele era separado de sua mãe, a qual escrevia uma carta informando a quem deveria ser entregue a criança e que nome ela teria. Depois disso, elas eram assassinadas ${ }^{27}$, sem saberem o real destino de seus filhos.

Para os militares, a apropriação ilegal de menores era parte do grande plano de "reorganização nacional", o qual tinha como escopo maior combater a ameaça "terrorista" comunista. Sob esse ponto de vista, eles argumentavam que as crianças estariam sendo

\footnotetext{
${ }^{23}$ Detidos ou desaparecidos, em português.

${ }^{24}$ Comissão Nacional sobre o Desaparecimento de Pessoas, em português.

${ }^{25}$ Escola de Mecânica da Armada, em português.

${ }^{26}$ Testemunha no julgamento do "Plano estadual sistemático para o rapto de menores", Buenos Aires, Argentina. Disponível no filme-documentário "500: Os bebês roubados pela ditadura argentina".

${ }^{27}$ Grande parte dos assassinatos dos detenidos-desaparecidos eram realizados por meio de "voos da morte". Adolfo Scilingo, oficial da ESMA, admitiu ter participado diretamente desses assassinatos. Em depoimento, disponível no filme-documentário "500: Os bebês roubados pela ditadura argentina", ele diz que aos presos contava-se que iam ser transferidos a um centro de detenção localizado ao sul. Eles tomavam uma forte dose de sonífero, o qual os mantinha desacordados. Ao sobrevoarem o Rio da Prata, seu destino final, os corpos eram arremessados.
} 
resgatadas, como uma salvação messiânica, dos inimigos do Estado argentino. Longe da ideologia "subversiva", os bebês seriam criados com base na educação cristã ocidental.

Liliana Sanjurjo (2013) ressalta como a missão de desaparecimento arquitetada pelos líderes do regime foi cumprida em seus detalhes. Segundo ela, foram suprimidas tanto as marcas da morte quanto as da vida, porque não só se elimina o inimigo, matando-o, mas também a identidade de seu filho, sequestrado, para não dar continuidade às lutas políticas de seus antecessores. Essa análise deixa claro como as crianças foram consideradas "espólios de guerra", apropriadas como objetos passíveis de troca.

Uma das provas da existência do plano foi um manual denominado Intrucciones sobre procedimiento a seguir com menores de edad, hijos de dirigentes politicos o gremiales, cuando sus progenitores se encuentran detenidos o desaparecidos ${ }^{28}$, em que havia ordens para doar a famílias ligadas aos militares, ou para orfanatos, crianças com até 4 anos de idade. Suas vidas eram poupadas porque eram novas e ainda podiam ser socializadas conforme os ideais do regime. Aquelas mais velhas, em torno dos seus 10 anos, já estavam “contaminadas", e por isso deveriam ser assassinadas (KOIKE, 2013).

Além dos militares, civis, magistrados, profissionais da área da saúde e agentes de cartórios também estavam auxiliando o sequestro e apropriação de menores. O parto e a documentação eram forjados, adulterando-se o nome, a idade e a filiação da criança. A identidade ia se perdendo desde o registro do menor, violentamente inserido em uma "lavagem" dos valores que compunham o legado de seus pais. Todavia, a verdadeira carga identitária, que foi pensada pelas “Avós”, estava em seu sangue - o DNA.

A fim de anistiarem os militares dos crimes de lesa-humanidade, foram criadas as leis de Ponto Final ( $\left.\mathrm{n}^{\mathrm{o}} 23.492 / 1986\right)$ e de Obediência Devida $\left(\mathrm{n}^{\mathrm{o}} 23.521 / 1987\right)$ durante a presidência de Raul Alfonsín, justificadas como necessárias para a manutenção da paz social. Elas foram decretadas logo após a condenação ${ }^{29}$ da Junta Militar por violações aos direitos humanos, dentre seus membros Jorge Videla, à época sentenciado à prisão perpétua. A impunidade dos agentes da ditadura não desestimulou as Abuelas, que continuaram sua busca pelos netos desaparecidos. Em 2005, a Corte Suprema de Justiça da Nação (CSJN) argentina considerou-as inconstitucionais.

As "Avós da Praça de Maio", unindo aproximadamente 30 casos, denunciaram um Plano Sistemático de Apropriação de Menores, praticado por meio de roubo e subtração de

\footnotetext{
${ }^{28}$ Instruções sobre o procedimento a ser seguido com menores de idade, filhos de líderes ou associados políticos, quando seus pais estão presos ou desaparecidos, em português.

${ }^{29}$ Os militares haviam sido julgados por sequestro, tortura e assassinato dos detenidos-desaparecidos, mas ainda não pela apropriação de menores.
} 
identidade de crianças entre 1976 e 1983. Julgado pelo $6^{\text {a }}$ Vara Federal Criminal, a sentença final foi dada em 2012, pela presidente do Tribunal, María Roqueta, comprovando a existência do plano. Ela condenou os ex-ditadores Jorge Rafael Videla e Reynaldo Bignone, além de outros atuantes nos crimes, pela prática de:

\begin{abstract}
"delitos de lesa-humanidade implantados mediante prática sistemática e generalizada de subtração, retenção e ocultação de menores de idade, tornando incerta, alterando ou suprimindo suas identidades, em razão de sequestro, cativeiro e desaparecimento ou morte de suas mães, enquadrados em um plano de aniquilação que se concretizou sobre parte da população civil, com o argumento de combater a subversão, implementando métodos de terrorismo de Estado entre os anos de $1976 \mathrm{e}$ 1983 da última ditadura militar" (500: Os bebês roubados pela ditadura argentina, 2014). ${ }^{30}$
\end{abstract}

O resultado do julgamento recompensou os anos de investigação e busca pelos netos promovidos pelas "Avós", que se viram não só apoiadas pela sociedade civil, mas então legitimadas pela justiça. O sentimento que, por bastante tempo, era de esperança, transformase em parte do dever cumprido: a sanção aos responsáveis pela apropriação de crianças.

\title{
3 FUNDAMENTOS JURÍDICOS DAS “AVÓS DA PRAÇA DE MAIO”
}

A proteção à dignidade da pessoa humana, aos direitos fundamentais, à identidade $\mathrm{e}$ à verdade é um compromisso assumido pelo Estado argentino. Tratados internacionais e suas próprias leis resguardam as garantias tão buscadas pelas "Avós", as quais encontram no direito o respaldo jurídico que legitima os trabalhos de pesquisa, investigação, denúncia, exame de DNA e restituição de identidade promovidos pela organização.

Segundo a Comissão Nacional sobre o Desaparecimento de Pessoas - CONADEP (1994), o sequestro dos detenidos-desaparecidos e apropriados, promovido durante a ditadura pelo governo argentino, é conceituado da seguinte forma em seu art. II:

Para os efeitos desta Convenção, entende-se por desaparecimento forçado a privação de liberdade de uma pessoa ou mais pessoas, seja de que forma for, praticada por agentes do Estado ou por pessoas ou grupos de pessoas que atuem com autorização,

\footnotetext{
${ }^{30}$ Sentença condenatória proferida pela presidente do Tribunal, María Roqueta, durante julgamento do "Plano estadual sistemático para o rapto de menores", em Buenos Aires, 2012. Disponível no filme-documentário "500: Os bebês roubados pela ditadura argentina".
} 
apoio ou consentimento do Estado, seguida de falta de informação ou da recusa a reconhecer a privação de liberdade ou a informar sobre o paradeiro da pessoa, impedindo assim o exercício dos recursos legais e das garantias processuais pertinentes (CONADEP, 1994)

Uma vez que a Argentina é um Estado Parte da Convenção (1994), o país tem o dever de não permitir a incidência de desaparecimentos forçados, punir os responsáveis pela prática, cooperar com os outros signatários para sua prevenção e tomar as medidas cabíveis para cumprir as garantias assumidas (CONADEP, 1994), como acordado no art. I.

Um ponto importantíssimo da CONADEP (1994), especialmente para as "Avós da Praça de Maio", diz respeito aos filhos dos desaparecidos. O art. XII deixa clara a responsabilidade assumida pelos signatários, os quais devem "cooperar na busca, identificação, localização e restituição de menores transportados a outro Estado ou retidos neste em consequência do desaparecimento forçado de seus pais" (CONADEP, 1994). O Estado argentino não pode, de forma alguma, obstruir o trabalho das Abuelas, e sim facilitálo, já que é também de seu interesse e dever a busca pelos netos apropriados.

Sob o mesmo ponto de vista, a Convenção da ONU sobre o Direitos da Criança (1989) define proteções que os Estados devem salvaguardar aos menores, seguranças essas que foram violadas pelo governo argentino à época da ditadura. $\mathrm{O}$ art. $7^{\circ}, 1$ estabelece que a criança deverá ser registrada imediatamente após seu nascimento, tendo direito de conhecer seus pais e de ser cuidada por eles. $\mathrm{O}$ art. $8^{\circ}$, por sua vez, compromete os Estados Partes a respeitarem o direito da criança de preservar sua identidade e suas relações familiares; no caso de privação dessa garantia, os Estados Partes devem prestar assistência a fim de restabelecer tal identidade.

Ainda sobre a referida Convenção (1989), os incisos 1 e 4 do art. $9^{\circ}$ dispõem que a criança não deverá ser separada de seus pais contra a vontade deles e, uma vez acontecendo sob custódia do Estado, os pais, a criança ou seus familiares devem ser informados a respeito do paradeiro de quem esteja ausente. Por fim, o art. 16, 1 regulamenta que nenhuma criança será alvo de interferências arbitrárias ou ilegais em sua vida particular, como em sua família.

Todas essas disposições estão negativamente ligadas ao passado argentino, já que foram transgredidas de forma sistemática, deixando uma dívida a qual poderá ser minimamente compensada com a identificação e restituição de identidade das crianças roubadas, hoje já adultas. Ademais, essas garantias incentivam o trabalho das "Avós", já que seus objetivos não estão limitados a sua própria atuação, mas são obrigações do Estado. Ele é 
o responsável pelas violações ocorridas na ditadura, por isso deve promover, ao máximo, mecanismos para reparar as consequências à sociedade argentina.

O Congresso Nacional da Argentina promulgou, em 26 de novembro de 2009, uma lei que reformulava o Código Penal argentino: a lei 26.548/2009, conhecida por Lei de $A D N$. $\mathrm{O}$ artigo $2^{\circ}$ da referida lei garante a obtenção de material genético necessário como prova para o esclarecimento de crimes de lesa-humanidade, permitindo a identificação de filhos de desaparecidos, sequestrados durante o regime militar, mediante o cruzamento de informações do Banco Nacional de Dados Genéticos (BNDG), além do auxílio à justiça e a organizações governamentais e não-governamentais empenhadas no referido objetivo.

A busca pela identidade, entretanto, nem sempre é desejada por aqueles que, possivelmente, foram sequestrados, embora as famílias reclamem o direito ao esclarecimento da verdade. Dessa realidade, surgiu o dilema entre direito à intimidade pessoal da vítima, a qual poderia se recusar a realizar o exame de DNA, e direito à justiça e à verdade dos familiares, os quais exigem o conhecimento da sua linhagem.

A prevalência da informação aos familiares das vítimas sobre qualquer recusa derivou de uma grande contribuição da Lei de $A D N$. Em seu art. 14 consta que o Banco Nacional de Dados Genéticos (BNDG) deverá fazer o cruzamento genético das informações ordenadas por um juiz competente ou pela Comissão Nacional pelo Direito à Identidade (CONADI), em virtude dos objetivos previstos no art. $2^{\circ}$. Portanto, ainda que o possível apropriado não se submeta voluntariamente ao exame de DNA, juízes podem emitir mandados de busca para obterem mostras de material genético em objetos de uso pessoal, como escova de cabelo, que serão analisados pelo BNDG.

A alternativa de extração de células não hemáticas avançou o trabalho de pesquisa e identificação dos netos das Abuelas. Isso porque muitos jovens foram encontrados após denúncias e medidas judiciais, já que se negavam a realizar o exame de sangue. Um deles foi Alejandro Pedro Sandoval Fontana, que descobriu sua verdadeira identidade em 2006, após o mandado da juíza federal Dra. María R. Servini de Cubría. Filho de Liliana Fontana e Pedro Sandoval, ele admite não ter feito voluntariamente o exame de DNA por causa da culpa que sentiria se não protegesse seu apropriador. Alejandro, defendendo a plena verdade, apoiou publicamente a Lei de $A D N$. 


\section{DIREITO À IDENTIDADE: A RESTITUIÇÃO DOS NETOS APROPRIADOS}

As “Avós”, na busca por seus netos, precisavam encontrar o elemento inquestionável para identificar os desaparecidos, possibilitando a restituição dos jovens. O aspecto físico é incerto, mas o DNA é preciso. Não importa onde nem com quem estejam, os apropriados guardarão em seu sangue a verdade sobre sua família biológica.

Foi pensando nisso que as "Avós" desenvolveram seus primeiros estudos sobre genética, em meados de 1982, quando receberam uma enorme contribuição de importantes geneticistas, como a estadunidense Mary Claire King, além de pesquisas com a Associação Americana pelo Progresso da Ciência. Em um Simpósio em Washington, em 1987, os mais recentes estudos em genética comprovaram que era possível identificar os laços de sangue por meio do cruzamento genético entre os apropriados e seus familiares paternos e maternos, não necessariamente seus pais. Essa descoberta foi de tamanha importância para as "Avós", porque a maioria de seus filhos estavam mortos, o que dificultava a comparação do DNA entre eles e os possíveis netos.

A primeira restituição em que se utilizou a análise genética como prova da identidade foi a de Paula Eva Logares, em 1984. Cinco anos depois, o Banco Nacional de Dados Genéticos (BNDG) foi criado pela lei 23.511/1989, a fim de armazenar os mapas genéticos de todas as famílias de crianças desaparecidas. Cada criança tem um processo em aberto na justiça, complementado pelo trabalho das "Avós". Os avanços nas investigações das Abuelas foram possíveis graças à colaboração dos estudos em genética, os quais foram igualmente beneficiados pelo trabalho da organização.

Entre 1978 e 2017, as “Avós” restituíram 122 netos, nascidos no centro de detenção onde suas mães estavam detidas ou sequestrados junto a seus pais. $\mathrm{O}$ último caso solucionado foi em 18 de abril de 2017, o qual promoveu a restituição de identidade do filho de Iris Nélida García, desaparecida grávida de 3 meses, e de Enrique Bustamante, ambos sequestrados em 31 de janeiro de 1977 e, até então, desaparecidos. O jovem se dirigiu voluntariamente ao Banco Nacional de Dados Genéticos (BNDG) para a realização do exame de DNA. O BNDG, em seguida, informou à Comissão Nacional pelo Direito à Identidade (CONADI) que se tratava do filho de Bustamante e García.

A verdadeira identidade é revelada por um simples exame de DNA, mas a restituição e aceitação desse fato dependem de um processo mais complexo. A fim de auxiliar os jovens 
a conhecerem seu passado e a história de seus pais biológicos, as Abuelas desempenham um importante trabalho de memória.

Nesse sentido, o Arquivo Biográfico Familiar, caracterizado como "facilitador da transmissão geracional que a ditadura pretendeu cercear” por Liliana Sanjurjo (2013, p. 213), é um mecanismo criado pela organização em 1998, para dar, aos jovens, informações que facilitem o processo de restituição. Nesse Arquivo, cada neto tem sua seção, em que é possível encontrar fotos de seus pais, relatos de familiares, amigos, companheiros de cativeiro e de militância. Ele aproxima o jovem de uma realidade até então desconhecida, difícil de ser aceita.

As “Avós” ressaltam que seu objetivo maior é conceder a verdade biológica aos seus netos, de forma objetiva e neutra, sem impor obrigações a eles a partir de então. Claramente a presença de um viés político é marcante nas restituições, mas não há nenhum apelo ideológico por parte das Abuelas. Para elas, depois de conhecer sua identidade, o neto é completamente livre de pensamento e de escolha. Mesmo assim, difíceis são aqueles que não se sentem parte do ativismo das "Avós da Praça de Maio" e do legado de seus verdadeiros pais, dando continuidade à memória de sua família.

Diante disso, é notório como o sangue guarda, por si só, uma verdade, que não é só biológica, mas histórica. $\mathrm{O}$ conhecimento da identidade não se limita a um genótipo; é muito mais sobre entender quem foram seus pais, suas ideologias e o motivo de terem seus direitos brutalmente violados. Restituir a identidade é buscar a memória de uma nação em amnésia, entendendo-se como personagem histórico de um passado de transgressões. Ser um jovem apropriado é reconhecer-se vítima da ditadura; é se autodeclarar filho de detenidosdesaparecidos. É nunca poder conhecer seus pais e, ainda assim, lutar por justiça, por verdade, por memória, por identidade.

\section{A JUSTIÇA DE TRANSIÇÃO ARGENTINA}

A transição entre a ditadura e a redemocratização argentina, na qual se insere a Justiça Retroativa ${ }^{31}$, é objeto de análise de muitos estudiosos, os quais procuram fornecer um olhar que por muito tempo permaneceu obscuro, auxiliando no resgate da memória e na reparação dos direitos humanos. Ela deve ser entendida como o conjunto de mecanismos

\footnotetext{
${ }^{31}$ Justiça Retroativa é outra denominação para Justiça de Transição, também chamada de Justiça Reparadora.
} 
utilizados para superar um momento de conflitos internos e de graves violações aos direitos humanos, ocorridas de forma sistemática a um grupo de pessoas. Trata-se, na verdade, de uma prestação de contas com o passado, essencial para pacificar a sociedade, possibilitando que esta evolua sem a constante recordação das feridas abertas pelas violações aos direitos humanos (TAVARES; AGRA, 2009, p. 71).

Para Mendéz (1997, p. 255), a Justiça de Transição possui quatro objetivos básicos: a) investigar, processar e punir os violadores de direitos humanos; b) revelar a verdade para a vítima, seus familiares e toda a sociedade; c) oferecer reparação adequada; d) afastar os criminosos de órgãos relacionados ao exercício da lei e de outras posições de autoridade. As “Avós da Praça de Maio", fundadas em decorrência das violações da ditadura militar, desenvolveram métodos e procedimentos para atender aos objetivos da Justiça de Transição e possibilitar uma abertura democrática ao Estado de Direito.

Como já analisado, as Abuelas, após muitas investigações, conseguiram comprovar a existência de um Plano Sistemático de Apropriação de Menores, garantindo a punição aos envolvidos no roubo de seus netos, desde os líderes militares até os médicos dos centros clandestinos de repressão. A Justiça de Transição, entretanto, não se limita à aplicação de uma penalidade. Muito embora não tenha como se anular os crimes cometidos, um dos papéis mais importantes da Justiça Reparadora é, como o nome sugere, reparar as consequências sociais de um período de extrema violência e repressão, prevenindo a sua reincidência.

Por isso, as “Avós da Praça de Maio" promovem a reconstrução da memória social da nação argentina, pautada na verdade histórica sobre o regime militar. No caso dos apropriados, elas concedem a identidade biológica, a chance de serem reinseridos em suas famílias e o conhecimento de seu passado, por meio, por exemplo, do Arquivo Biográfico Familiar.

Na Argentina, o trabalho de verdade e memória coletiva é amplamente difundido, visando atingir o maior número de pessoas, o que também possibilita o encontro de mais jovens apropriados. As “Avós” organizam passeatas, manifestações, concertos, palestras e outras formas de comunicação social. A televisão argentina divulga propagandas incentivando jovens que têm dúvidas sobre sua identidade a procurarem a organização. Ademais, novelas e documentários foram filmados, baseando-se em casos reais, para contar a história dos desaparecidos e dos apropriados, a qual foi omitida da sociedade durante violentos anos. 
A antiga ESMA foi reformada para promover um espaço de memória e direitos humanos, transformando-se, em 2014, em Casa por la Identidad ${ }^{32}$. Lá se narra a luta das "Avós da Praça de Maio", desde o desaparecimento de seus filhos até a identificação dos netos, em uma ilustre exposição de fotos e textos, além de relatos e palestras. Pela Casa por la Identidad passam famílias, crianças, adultos, grupos escolares e até celebridades internacionais. Eles podem ser acompanhados de guias que facilitam o conhecimento do ambiente, proporcionando um fácil entendimento sobre as Abuelas e sobre as consequências negativas da ditadura, as quais não devem se repetir.

Graças aos dedicados trabalhos das "Avós da Praça de Maio", elas receberam, em 2011, a edição de 2010 do prêmio "Félix Houphouet-Boigny pela Busca da Paz" da Unesco (Organização da ONU para Educação, Ciência e Cultura). Segundo o ministro argentino das Relações Exteriores, Héctor Timerman, "as Avós foram premiadas porque a persistente busca de seus netos é exemplo para todo o mundo e reafirma a vontade de se construir um futuro com memória, verdade e justiça". As Abuelas são um espelho, principalmente, para países que atravessaram semelhante situação de ditadura militar, mas que ainda não conseguiram superar esses anos de chumbo, como é o caso de muitas nações latino-americanas, em especial o Brasil.

Sem dúvida, elas deram os primeiros passos para efetivar a Justiça de Transição na Argentina, a qual não teria sido tão bem desenvolvida sem o compromisso das Abuelas. $\mathrm{O}$ mais encantador da organização é o sentimento coletivo das "Avós", que, apesar de terem perdido seus filhos, não desanimaram para identificar seus netos, promover incansáveis investigações, fazer denúncias e deixar como herança a verdade, a justiça e a memória para toda a comunidade argentina.

\section{CONSIDERAÇÕES FINAIS}

O sequestro, detenção, tortura e assassinato de pessoas durante a ditadura militar argentina (1976-1983) desencadearam a união de mães que, desesperadas, exigiam o conhecimento do paradeiro de seus filhos. Iniciaram por motivos individuais, sem saber que, no futuro, seriam dedicadas a uma nação. As “Avós da Praça de Maio", apesar de não poderem recuperar seus filhos, visam à restituição de seus netos. Além disso, buscam tecer, na

\footnotetext{
${ }^{32}$ Casa pela Identidade, em português.
} 
memória coletiva, uma parte da história em que há vácuo, escondida da sociedade civil por militares que cometeram crimes de lesa-humanidade.

O direito à identidade é uma concessão das "Avós" que possibilita ao jovem reinserir-se na sua linha filiatória. Apesar de não poderem conhecer seus pais, o sangue transmite um legado imutável. Como apontado por Liliana Sanjurjo (2013, p. 222), "quando uma pessoa conhece sua origem genética, reconhece seu vínculo social verdadeiro". A restituição permite herdar, de seus pais, valores morais e uma causa social, os quais compõem a personalidade identitária dos apropriados. A identidade, a verdade e as convicções daqueles que foram restituídos serão, da mesma forma, transmitidos às gerações futuras.

Sob a mesma análise, a verdade histórica é um pilar da Justiça de Transição. Nenhum regime autoritário será superado se a completa verdade não for conhecida pela comunidade nacional e, também, internacional. É por meio dela que a memória de um povo em amnésia é recuperada, que a democracia é restituída e que crimes contra a humanidade são prevenidos. Todas as atividades das Abuelas são pautadas na verdade, com investigações, denúncias, declarações e exames de sangue neutros e objetivos.

Inquestionavelmente, as consequências dos trabalhos das "Avós da Praça de Maio" são uma efetiva Justiça Reparadora. Para a sociedade argentina, as "Avós" simbolizam a reconstrução da memória do regime militar e a transição de um autoritarismo para uma democracia. Para as crianças sequestradas pelos militares, hoje já adultas, a organização promoveu a restituição de suas identidades biológicas, oferecendo exames de DNA que comprovaram a verdade por trás de um passado falacioso.

Para a história, as investigações preenchem lacunas ou retificam acontecimentos mal contados, deixando um legado indelével. Para as vítimas da ditadura e para seus familiares, as “Avós" oferecem a justiça, a visibilidade de suas contestações sociopolíticas e um ativismo em respeito à dignidade humana. Para os militares responsáveis pelas violações aos direitos humanos, garantem-se as justas punições pelas atrocidades cometidas durante a ditadura.

\section{REFERÊNCIAS}

ABUELAS de Plaza de Mayo. Historia. Disponível em: < https://abuelas.org.ar/abuelas/historia-9>. Acesso em: 24 mai.2017 
- Casos resueltos: Bustamante García. Disponível em: < https://abuelas.org.ar/caso/bustamante-garcia-126?orden=c>. Acesso em: 24 mai.2017

Casos resueltos: Paula Eva Logares. Disponível em: < https://www.abuelas.org.ar/caso/logares-paula-eva-243?orden=c >. Acesso em: 19 jun.2017

Casos resueltos: Alejandro Pedro Sandoval Fontana. Disponível em: < https://www.abuelas.org.ar/caso/sandoval-fontana-alejandro-pedro-298?orden=c $>$. Acesso em: 18 jun. 2017

Casa por la Identidad. Disponível em: < https://www.abuelas.org.ar/abuelas/casala-identidad-12>. Acesso em: 20 jun.2017

ARGENTINA. Lei 26.548, de 26 de novembro de 2009. Banco Nacional de Datos Geneticos. Disponível em: <http://servicios.infoleg.gob.ar/infolegInternet/anexos/160000164999/160772/norma.htm>. Acesso em: 22 mai.2017

CARMO, Marcia. Unesco premia Avós da Praça de Maio por ações em busca da paz. Estadão Internacional. Disponível em: $<$ http://internacional.estadao.com.br/noticias/geral, unesco-premia-avos-da-praca-de-maiopor-acoes-em-busca-da-paz,687401>. Acesso em: 20 jun.2017

CHEHAB, Isabelle Maria Campos Vasconcelos. CRUZ, Marco Aurélio Rodrigues da Cunha e. Perspectivas e desafios de comissões bi ou plurinacionais da verdade. Florianópolis: CONPEDI, 2016, p. 62-78. Disponível em: <https://www.conpedi.org.br/publicacoes/9105o6b2/215rx7ce/D61V5V81rSlfhIi7.pdf>. Acesso em: 11 abr.2017

GUEMBE, María José. Reabertura dos processos pelos crimes da ditadura militar argentina. São Paulo: Revista Internacional de Direitos Humanos, vol. 2, nº 3, 2005.

KOIKE, Maria Lygia. O sequestro de crianças pela ditadura militar Argentina e atuação das Avós da Praça de Maio pelo direito à verdade (jurídica e biológica) e à memória. Paraíba: Revista Gênero e Direito, vol. 1, 2013, p.1-24. 
MENDÉZ, Juan E. Accountability for past abuses. Human Rights Quartely. Baltimore, v. 19, n. 2, p. 255, May, 1997.

ORGANIZAÇÃO DAS NAÇÕES UNIDAS (ONU). Convenção sobre os Direitos da Criança. Disponível em: <https://www.unicef.org/brazil/pt/resources_10120.htm>. Acesso em: 23 mai. 2017

ORGANIZAÇÃO DOS ESTADOS AMERICANOS (OEA). Convenção Americana dos Direitos Humanos. Disponível em: < https://cidh.oas.org/Basicos/Portugues/c.Convencao_Americana.htm>. Acesso em: 23 mai.2017

Convenção Interamericana sobre o Desaparecimento de Pessoas. Disponível em: < https://cidh.oas.org/Basicos/Portugues/k.Desaparecimento.htm>. Acesso em: 23 mai.2017 SANJURJO, Liliana. La Sangre no Miente: Memória, identidade e verdade na Argentina pósditatorial. Campinas: Revista de Antropologia da UFSCAR, v.5, n.2, jul.-dez., p.200-224, 2013

SILVA, Ricardo Guilherme Silveira Corrêa. Direito à verdade e as futuras gerações: a projeção do passado no futuro da sociedade. Florianópolis: CONPENDI, 2016. Disponível em:<https://www.conpedi.org.br/publicacoes/9105o6b2/bnt1rvpf/A2Y1aN6GWnH6L17s.pdf >. Acesso em 11 abr.2017

TAVARES, André Ramos; AGRA, Weber de Moura. Justiça reparadora no Brasil. In: SOARES, Inês Virginia Prado, KISHI, Sandra Akemi Shimada (Coord.). Memória e Verdade: a justiça de transição no Estado Democrático Brasileiro. Belo Horizonte: Fórum, 2009.

VAL, Eduardo Manuel. MOURA, Emerson Affonso da Costa. Justiça de Transição, ditadura militar e sistema de proteção dos direitos humanos: os papéis das Cortes Constitucionais latino-americanas diante das decisões da Corte Interamericana de Direitos Humanos sobre a Anistia. Florianópolis: CONPEDI, 2016, p. 132-152. Disponível em: 
<https://www.conpedi.org.br/publicacoes/9105o6b2/081s6j67/zSVAY4mpAth4KWTt.pdf>. Acesso em 11 abr.2017

VALENTI, Alexandre. 500: Os bebês roubados pela ditadura argentina [filme-documentário]. Brasil, Petrobras, 2014. 105 min.

TRANSITIONAL JUSTICE: “ABUELAS DE PLAZA DE MAYO” AS AGENTS OF THE RIGHT TO IDENTITY AND TO ARGENTINA'S HISTORICAL TRUTH

\begin{abstract}
The article intends to prove the eminent contribution of the "Abuelas de Plaza de Mayo" to the Transitional Justice and, consequently, to the Argentine society, in view of their works dedicated to discover the truth, specially the historical and biological veracity, which makes possible to restore the right to identity of children who were kidnapped by the government during the Argentine military dictatorship (1976-1983). For that, the dialogic method is used, approaching the subject with several areas of knowledge besides law, as with anthropology, biology, history and sociology. Combating crime of appropriation, "Abuelas de Plaza de Mayo" are legally and scientifically backed to carry out investigations, data collection, research, DNA tests and psychological repair of those who had their identity restored, which establishes their organization as an international model of a restorative activism in favor of memory and of a just transition to democracy.
\end{abstract}

Keywords: Transitional Justice. Right to identity. Right to truth. Abuelas de Plaza de Mayo. Argentine military dictatorship. 